Article

\title{
Apparent Yield Stress of Sputum as a Relevant Biomarker in Cystic Fibrosis
}

\author{
Rosy Ghanem ${ }^{1, * \mathbb{C}}$, Philippe Roquefort ${ }^{2}$, Sophie Ramel ${ }^{3}$, Véronique Laurent $^{1}$, Tanguy Haute ${ }^{1} \mathbb{D}$, \\ Tony Le Gall ${ }^{1}\left(\mathbb{D}\right.$, Thierry Aubry ${ }^{2, *}$ and Tristan Montier $1,4, * \mathbb{D}$ \\ 1 Univ. Brest, INSERM, EFS, UMR 1078, GGB, F-29200 Brest, France; Veronique.Laurent@univ-brest.fr (V.L.); \\ Tanguy.Haute@univ-brest.fr (T.H.); Tony.Legall@univ-brest.fr (T.L.G.) \\ 2 Univ. Brest, IRDL UMR CNRS 6027, UFR Sciences et Techniques, 6, Avenue Victor Le Gorgeu CS 93837, \\ CEDEX 3, 29238 Brest, France; Philippe.Roquefort@univ-brest.fr \\ 3 Centre de Ressources et de Compétences de la Mucoviscidose, Fondation Ildys, Presqu'île de Perharidy, \\ 29680 Roscoff, France; Sophie.Ramel@ildys.org \\ 4 CHRU de Brest, Service de Génétique Médicale et Biologie de la Reproduction, Centre de Référence des \\ Maladies Rares "Maladies Neuromusculaires", F-29200 Brest, France \\ * Correspondence: Rosy.Ghanem@univ-brest.fr (R.G.); Thierry.Aubry@univ-brest.fr (T.A.); \\ Tristan.Montier@univ-brest.fr (T.M.)
}

check for updates

Citation: Ghanem, R.; Roquefort, P.; Ramel, S.; Laurent, V.; Haute, T.; Le Gall, T.; Aubry, T.; Montier, T. Apparent Yield Stress of Sputum as a Relevant Biomarker in Cystic Fibrosis. Cells 2021, 10, 3107. https://doi.org/ 10.3390/cells10113107

Academic Editor: Michael Gray

Received: 13 October 2021

Accepted: 6 November 2021

Published: 10 November 2021

Publisher's Note: MDPI stays neutral with regard to jurisdictional claims in published maps and institutional affiliations.

Copyright: (c) 2021 by the authors. Licensee MDPI, Basel, Switzerland. This article is an open access article distributed under the terms and conditions of the Creative Commons Attribution (CC BY) license (https:// creativecommons.org/licenses/by/ $4.0 /)$.

\begin{abstract}
The mucus obstructing the airways of Cystic Fibrosis (CF) patients is a yield stress fluid. Linear and non-linear rheological analyses of CF sputa can provide relevant biophysical markers, which could be used for the management of this disease. Sputa were collected from CF patients either without any induction or following an aerosol treatment with the recombinant human DNAse (rhDNAse, Pulmozyme ${ }^{\circledR}$ ). Several sample preparations were considered and multiple measurements were performed in order to assess both the repeatability and the robustness of the rheological measurements. The linear and non-linear rheological properties of all CF sputa were characterized. While no correlation between oscillatory shear linear viscoelastic properties and clinical data was observed, the steady shear flow data showed that the apparent yield stress of sputum from CF patients previously treated with rhDNAse was approximately one decade lower than that of nontreated CF patients. Similar results were obtained with sputa from non-induced CF patients subjected ex vivo to a Pulmozyme ${ }^{\circledR}$ aerosol treatment. The results demonstrate that the apparent yield stress of patient sputa is a relevant predictive/prognostic biomarker in CF patients and could help in the development of new mucolytic agents.
\end{abstract}

Keywords: airway mucus; rheology; biomarker; Cystic Fibrosis

\section{Introduction}

Cystic Fibrosis (CF) is a genetic disorder affecting multiple organs, the lungs being those whose failure leads to premature death [1]. The pathology is due to mutations in the $c f t r$ gene encoding the Cystic Fibrosis Transmembrane conductance Regulator (CFTR) protein, the most frequent one being the F508del mutation. The CFTR is a channel that controls the excretion of chloride ions and negatively regulates the activity of the epithelial sodium channel (ENaC) [2]. As a consequence of mutation(s) occurring in the cftr gene, ionic dysregulation, causing massive water reabsorption, is responsible for the sticky dehydrated mucus covering the epithelial cells of the lung airways. This provides a favorable environment for bacteria colonization, which induces chronic inflammation and modifies the viscoelastic properties of the mucus. Moreover, CF mucus notably contains increased levels of DNA primarily derived from the disintegration of inflammatory cells such as neutrophils, leading to an increase in sputum viscosity [3]. The accumulation of a viscous mucus in the respiratory tract, combined with the bacterial infection and immune response, progressively lead to the destruction of the pulmonary parenchyma and, ultimately, to 
lung failure. The use of small drugs to modulate and/or potentiate the CFTR protein functions represents a promising strategy for the treatment of CF patients. The most recent therapy approved by the FDA and EMA is a tritherapy combining ivacaftor, elexacaftor and tezacaftor (Kaftrio ${ }^{\circledR}$, Vertex Pharmaceuticals, Boston, MA, USA) [4,5]. However, this approach is mutation-dependent and therefore cannot be applied to all CF patients. Additionally, some patients have developed adverse effects, leading to the interruption of their pharmacological treatment [6,7]. Gene therapy is also a promising alternative to CF protein treatments as it is independent of mutation profiles and could thus offer real benefit to all patients; however, long-term tolerance is still unknown. To administrate such treatments, aerosol delivery represents an ideal method to target the pulmonary epithelium as it is a non-invasive, loco-regional administration method that allows us to bypass the hepatic first-pass effect. The latest non-viral gene therapy trial was performed using aerosol delivery of a formulation based on the cationic lipid GL67 [8]. Although an increase of $3.7 \%$ in the FEV1 (forced expiratory volume in one second) was observed during the clinical study, no significant clinical improvement was recorded in patients. This disappointing result may be partly explained by the presence of the CF mucus covering the respiratory tract, which impedes nanolipoplexes (as well as recombinant viruses) from reaching the underlying target epithelium [9]. In this respect, mucus is a key barrier that gene delivery has to overcome in order to be successful. The role played by mucus as a complex fluid, i.e., a structured medium with complex rheological properties, has attracted much attention for a long time [10-12]. For instance, a rheological study performed on sputa from CF patients treated with rhDNAse (Pulmozyme ${ }^{\circledR}$ ), which is currently the main mucolytic treatment indicated before a physiotherapy session, has shown a reduction in the sputum viscosity, bringing a clinical benefit [13]. Bacterial infection was also proven to influence the rheological behavior of the mucus by increasing both its storage modulus and Newtonian viscosity [14]. A very recent study suggests that a critical stress, defined as the stress at which the storage (elastic) modulus is equal to the viscous (loss) modulus, could be a possible marker of chronic diseases [15]. However, in their paper, the authors used a homogenization method prior to rheological characterization, which could have impacted the rheological properties of the patients' sputa. Moreover, the critical stress that the authors defined was obtained in a non-linear regime, where a Fourier analysis is needed [16], meaning that the storage and loss moduli used to define the critical stress are only part of the response. In the present work, we aim at studying the linear and non-linear rheological properties of non-pre-sheared CF sputa, using both linear oscillatory shear and steady shear flow, in order to determine a biophysical marker of CF patient mucus rheology.

\section{Materials and Methods}

\subsection{Sputum Collection}

Sputa from CF patients were collected at the "Centre de Ressources et de Compétences de la Mucoviscidose (CRCM)" in Roscoff (France). Patients, or the parents of underage patients, were informed about the purpose of the study. Sputum collection was considered clinical waste and no patient intervention was necessary for this study. For a given patient, sputum was obtained either by spontaneous expectoration or following Pulmozyme ${ }^{\circledR}$ induction. Patient clinical data were anonymized and kept confidential; they were correlated to rheological measurements. Sputa were stored at $-20{ }^{\circ} \mathrm{C}$ and then carried on ice to the laboratory, where they were stored at $-20^{\circ} \mathrm{C}$ prior to rheological testing. Non-CF mucus was obtained by washing (with $5 \mathrm{~mL}$ of $0.9 \% \mathrm{NaCl}$ ) an endotracheal tube used during the heart surgery of a patient without lung disease. This material as well as its content were considered clinical waste and no additional procedure was necessary for the purpose of this study. After washing, the mucus was stored at $-20^{\circ} \mathrm{C}$ before rheological experiments. 


\subsection{Patient Demographics}

This study included sputa from 20 subjects (10 men and 10 women) with an average age of $32 \pm 8$ years at the time of sputum collection (Table 1). The oldest subject was 58 years old while the youngest was 5 years old. All patient sputa were found colonized by bacteria, 18 containing Pseudomonas aeruginosa. Only four patients experienced pulmonary exacerbations during the study period. The average FEV1 was 50\% $\pm 16 \%$, corresponding to moderate to severe pulmonary insufficiencies.

Table 1. Clinical data of CF patients at the time of sputum collection.

\begin{tabular}{|c|c|c|c|c|c|c|}
\hline Patient & Birth Year & Gender* & Mutation & FEV1 & Bacteria & Sputum Induction \\
\hline 1 & 1988 & W & F508 del/F508 del & $55 \%$ & Achromobacter spp. & No \\
\hline 2 & 2000 & M & F508 del/F508 del & $88 \%$ & $\begin{array}{c}\text { MSSA }^{* *} \\
\text { Staphylococcus aureus }\end{array}$ & No \\
\hline 3 & 1993 & M & 357 del C/357 del C & $30 \%$ & P. aeruginosa & No \\
\hline 4 & 1961 & M & N1303K/1898 + 5 G > A & $46 \%$ & $\begin{array}{l}\text { P. aeruginosa } \\
\text { Escherichia coli }\end{array}$ & rhDNAse \\
\hline 5 & 1978 & M & W 1282 X/R117H & $73 \%$ & $\begin{array}{c}\text { MSSA } \\
\text { P. aeruginosa }\end{array}$ & rhDNAse \\
\hline 6 & 1985 & W & F508 del/G542X & $30 \%$ & $\begin{array}{c}\text { MSSA } \\
\text { P. aeruginosa } \\
\text { Stenotrophomonas } \\
\text { maltophilia }\end{array}$ & No \\
\hline 7 & 1991 & W & F508 del/F508 del & $49 \%$ & $\begin{array}{c}\text { MSSA } \\
\text { P. aeruginosa }\end{array}$ & No \\
\hline 8 & 1996 & W & F508 del/F508 del & $35 \%$ & $\begin{array}{l}\text { Achromobacter spp. } \\
\text { P. aeruginosa }\end{array}$ & rhDNAse \\
\hline 9 & 1987 & W & F508 del/F508 del & $30 \%$ & $\begin{array}{l}\text { MRSA }{ }^{* * *} \\
\text { P. aeruginosa }\end{array}$ & No \\
\hline 10 & 1975 & W & F508 del/F508 del & $53 \%$ & Burkholderia cenocepacia & No \\
\hline 11 & 1987 & W & F508 del/91 (G-R) & $66 \%$ & P. aeruginosa & rhDNAse \\
\hline 12 & 1974 & M & F508 del/F508 del & $45 \%$ & P. aeruginosa & rhDNAse \\
\hline 13 & 2006 & M & F508 del/F508 del & $93 \%$ & $\begin{array}{c}\text { Haemophilus influenza } \\
\text { SSA }\end{array}$ & rhDNAse \\
\hline 14 & 1989 & W & F508 del/w882x & $31 \%$ & $\begin{array}{c}\text { P. aeruginosa } \\
\text { Candida albicans }\end{array}$ & No \\
\hline 15 & 1979 & M & F508 del/F508 del & $30 \%$ & $\begin{array}{c}\text { MSSA } \\
\text { P. aeruginosa }\end{array}$ & rhDNAse \\
\hline 16 & 1980 & M & F508 del/G411X & $53 \%$ & $\begin{array}{c}\text { MSSA } \\
\text { P. aeruginosa }\end{array}$ & No \\
\hline 17 & 1985 & $\mathrm{~W}$ & F508 del/F508 del & $23 \%$ & $\begin{array}{l}\text { Aspergilus fumigatus } \\
\text { P. aeruginosa }\end{array}$ & rhDNAse \\
\hline 18 & 1982 & M & F508 del/F508 del & $35 \%$ & P. aeruginosa & No \\
\hline 19 & 1985 & W & F508 del/F508 del & $70 \%$ & $\begin{array}{c}\text { MSSA } \\
\text { P. aeruginosa }\end{array}$ & No \\
\hline 20 & 2014 & M & F508 del/4005 G > A & $114 \%$ & $\begin{array}{l}\text { H. influenza } \\
\text { MSSA }\end{array}$ & No \\
\hline
\end{tabular}

\footnotetext{
${ }^{*} \mathrm{M}=$ man and $\mathrm{W}=$ woman, ${ }^{* *} \mathrm{MSSA}=$ Methicillin-Susceptible Staphylococcus aureus, ${ }^{* * *}$ MRSA $=$ Methicillin-Resistant Staphylococcus aureus.
} 


\subsection{Rheological Experiments}

Plane simple shear rheological experiments were carried out on $\sim 0.6 \mathrm{~mL}$ sputa samples at $37^{\circ} \mathrm{C}$ with a MCR702 Anton Paar rheometer. Two types of rheometrical tests were performed: oscillatory shear tests were used to characterize the linear viscoelastic moduli $\mathrm{G}^{\prime}$ (storage modulus) and G" (loss modulus), and steady shear tests were used to characterize the flow behavior (apparent viscosity $\eta$ as a function of shear stress $\tau$ ) of sputa. The viscoelastic and flow properties of all samples were measured using a cone and plate geometry (diameter: $50 \mathrm{~mm}$, cone angle: $1^{\circ}$, truncation: $100 \mu \mathrm{m}$ ); sandblasted parallel plates (diameter $25 \mathrm{~mm}$, gap: $1 \mathrm{~mm}$ ) were also used to investigate possible slip effects. For all sputa tested, a thin layer of low-viscosity silicone oil was placed at the air/sample interface in order to prevent evaporation. The characterization of the linear viscoelastic properties was performed using a two-step protocol: first, a strain sweep experiment at a fixed angular frequency of $1 \mathrm{rad}^{-1} \mathrm{~s}^{-1}$, allowing us to determine the linear viscoelastic regime (sinusoidal response and stress proportional to the magnitude of the applied strain), followed by a frequency sweep from 100 to $0.1 \mathrm{rad}^{-1} \mathrm{~s}^{-1}$, at a fixed strain amplitude of $1 \%$, which lay within the linear regime for all samples tested. Flow curves of all samples were obtained using shear rate sweep experiments, from 0.01 to $1000 \mathrm{~s}^{-1}$. For the more viscous samples, creep experiments in the linear response regime were also performed in order to obtain the zero-shear Newtonian viscosity.

\subsection{Ex Vivo Treatment of Mucus}

A sample of sputum previously collected from a non-induced patient (p18) was thawed at room temperature and placed on a Petri dish inside an exposure box $(12 \times 8.3 \times 6.7 \mathrm{~cm})$. Pulmozyme $^{\circledR}$ (rhDNAse, $2500 \mathrm{IU} / 2.5 \mathrm{~mL}$, Roche) was aerosolized using the eFlow ${ }^{\circledR}$ Rapid Nebulizer (PARI, France). Rheological characterization was performed immediately after this treatment. Furthermore, Istendo ${ }^{\circledR}$ (N-acetyl-cysteine, $1 \mathrm{~g} / 5 \mathrm{~mL}$, Laboratoires Delbert) was deposited on another sample of p18 sputum and directly analyzed in rheology.

\subsection{Statistical Analyses}

Data were analyzed using GraphPad Prism. To assess statistical difference, the nonparametric Mann-Whitney test was performed. Differences were considered statistically significant for $p$ values $<5 \%$.

\section{Results}

\subsection{Preliminary Rheometrical Results}

In the present work, sputa were harvested from $20 \mathrm{CF}$ patients either by spontaneous expectoration or after rhDNAse induction. For each patient, the $c f t r$ mutation as well as the FEV1 and the bacterial infections were recorded (Table S1). All sputa were stored at $-20{ }^{\circ} \mathrm{C}$ prior to rheological characterization [8]. As previous studies have suggested various preparation standardized protocols, such as saliva removal or vortex homogenization, in order to homogenize samples prior to testing $[15,17]$, the possible effect of sample centrifugation on the rheological behavior was first investigated by centrifugation at $2000 \times g$ for $10 \mathrm{~min}$. In the present work, no significant effect of centrifugation on the rheological response was ever observed (Figure 1); thus, all sputa were used per se, without any preparation prior to rheological measurements, which allowed us to eliminate any artefacts. Moreover, repeatability was shown to be satisfactory, as assessed with samples for which a sufficient volume was available (Figure 1). Lastly, using parallel plates with different roughness, we demonstrated that no significant slip occurred during the flow experiments (Figure S1). However, it is worth pointing out that the volume of some patients' sputa was too small to allow complete rheological characterization, including repeatability, slip effects and centrifugation effects. 

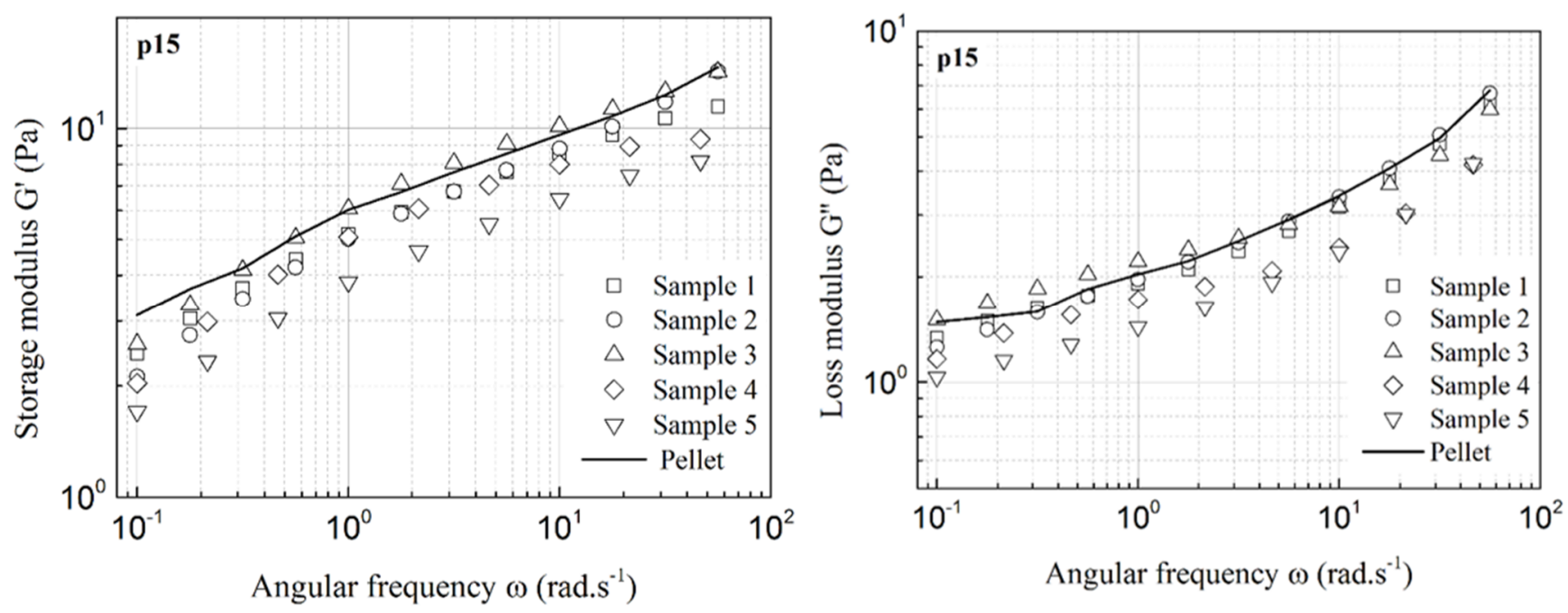

Figure 1. Repeatability and effect of centrifugation: storage modulus $\left(G^{\prime}\right)$ and loss modulus $\left(G^{\prime \prime}\right)$ for 6 samples taken from the same sputum (obtained from patient p15); sample 6 is the pellet obtained after centrifugation at $2000 \times g$, for $10 \mathrm{~min}$.

\subsection{Linear and Non-Linear Rheological Characterization}

For all samples, the viscoelastic moduli $\mathrm{G}^{\prime}$ and $\mathrm{G}^{\prime \prime}$ were first studied as a function of strain in order to determine the extent of the linear viscoelastic regime (Figure S2). Then, frequency sweep experiments were carried out at a $1 \%$ strain amplitude, chosen in the linear viscoelastic domain. $G^{\prime}$ and $G^{\prime \prime}$, as well as $G^{\prime \prime} / G^{\prime}$ at 0.1 rad.s ${ }^{-1}$ and at 10 rad.s ${ }^{-1}$, for all samples are given in Table 2 . No correlation between clinical data and $G^{\prime}, G^{\prime \prime}$ data was observed. However, as highlighted in Figure 2A, standard deviations of both $\mathrm{G}^{\prime}$ and $\mathrm{G}^{\prime \prime}$ were noticeably much lower in the rhDNAse induction group. Using exactly the same experimental procedure for all samples, i.e., shear rate sweep experiments, the flow curves of all sputa were also characterized. They all exhibited the same features: a Newtonian behavior at low stresses, followed by a very sharp decrease in the apparent viscosity, which appeared to be a near discontinuity. The stress threshold in the non-linear part of the flow curve can be identified with an apparent yield stress $\left(\tau_{\gamma}\right)$. It is worth pointing out that $\tau_{\gamma}$ is not a parameter characterizing a material at a given temperature and pressure but, rather, a protocol-dependent threshold parameter characterizing the stress needed to make a material flow [18]. The Newtonian viscosity and apparent yield stress for all samples are given in Table 2. The presence of an apparent yield stress in the flow curve of sputa was ascribed to the shear-induced fracture of a transient network, relatively similar to what is observed in associative polymers [19-21]. Most remarkably, two groups of patients can be distinguished when considering the value of the apparent yield stress: one with a yield stress of approximately $1 \mathrm{~Pa}$, which is also observed for non-CF mucus, and the other one with an apparent yield stress approximately one decade higher (Figure 2B). Most interestingly, sputa inducted with rhDNAse, as well as non-CF sputum, belong to the lower yield stress group, whereas spontaneous sputa correspond to the higher yield stress group, except for three patients (Table 2 and Figure 2). Moreover, comparison of the standard deviations shows that the yield stress dispersion is much lower in the rhDNAse induction group than in the spontaneous sputum group. In addition, data in Figure 2B show that the Newtonian viscosity level of both groups is different, the treated group having, on average, a slightly lower Newtonian viscosity than the non-treated one, as previously observed [13,22]. However, the difference between the two groups is significantly less pronounced when considering the Newtonian viscosity, and the variability in viscosity is also much greater than that in yield stress for non-treated patients. In this respect, the apparent yield stress appears to be a much more sensitive and accurate rheological parameter than viscosity to characterize the effect of rhDNAse induction. 
Table 2. Rheological characterization of CF sputa collected from patients who were previously treated, or not, with rhDNAse. The sputum obtained from a non-CF patient (collected by washing an endotracheal tube used during heart surgery) was used a reference. $G^{\prime}$ and $G^{\prime \prime}$ data were measured at a strain amplitude of $1 \%$ and at an angular frequency of 0.1 rad.s $\mathrm{s}^{-1}$ and 10 rad.s ${ }^{-1}$.

\begin{tabular}{|c|c|c|c|c|c|c|c|c|c|}
\hline \multirow{3}{*}{ Patient } & \multirow{3}{*}{ Pretreatment } & \multicolumn{6}{|c|}{ Oscillatory Shear } & \multicolumn{2}{|c|}{ Steady Shear } \\
\hline & & \multicolumn{3}{|c|}{$0.1{\mathrm{rad} . \mathrm{s}^{-1}}^{-1}$} & \multicolumn{3}{|c|}{10 rad.s $^{-1}$} & \multirow[b]{2}{*}{$\eta$ (Pa.s) } & \multirow[b]{2}{*}{$\tau_{y}(\mathrm{~Pa})$} \\
\hline & & $\mathrm{G}^{\prime}(\mathbf{P a})$ & $\mathrm{G}^{\prime \prime}(\mathbf{P a})$ & $\begin{array}{c}\tan \delta \\
\left(G^{\prime \prime} / G^{\prime}\right)\end{array}$ & $\mathrm{G}^{\prime}(\mathbf{P a})$ & $\mathrm{G}^{\prime \prime}(\mathbf{P a})$ & $\begin{array}{c}\tan \delta \\
\left(G^{\prime \prime} / G^{\prime}\right)\end{array}$ & & \\
\hline 1 & No & 5.3 & 1.8 & 0.34 & 10.3 & 2.5 & 0.24 & 290 & 13 \\
\hline 2 & No & 36 & 13 & 0.36 & 81 & 19 & 0.23 & 1400 & 48 \\
\hline 3 & No & 2.8 & 1.3 & 0.46 & 6.7 & 1.8 & 0.27 & 150 & 10 \\
\hline 4 & rhDNAse & 1.2 & 0.5 & 0.42 & 2.6 & 0.75 & 0.29 & 35 & 2 \\
\hline 5 & rhDNAse & 3.1 & 0.9 & 0.29 & 6.5 & 1.7 & 0.26 & 185 & 14 \\
\hline 6 & No & 3.3 & 1.2 & 0.36 & 6.9 & 1.8 & 0.26 & 160 & 19 \\
\hline 7 & No & 5.4 & 2 & 0.37 & 12.2 & 3.1 & 0.25 & 270 & 14 \\
\hline 8 & rhDNAse & 2.0 & 1 & 0.50 & 4.6 & 1.4 & 0.30 & 70 & 4 \\
\hline 9 & No & 0.2 & 0.1 & 0.50 & 0.7 & 0.36 & 0.51 & 7 & 0.1 \\
\hline 10 & No & 9.5 & 3.7 & 0.39 & 20 & 4.5 & 0.23 & 400 & 14 \\
\hline 11 & rhDNAse & 2.3 & 1.1 & 0.48 & 6.2 & 2 & 0.32 & 60 & 2 \\
\hline 12 & rhDNAse & 1.6 & 0.9 & 0.56 & 4.5 & 1.5 & 0.33 & 60 & 3 \\
\hline 13 & rhDNAse & 2.4 & 0.8 & 0.33 & 5.2 & 1.3 & 0.25 & 120 & 4 \\
\hline 14 & No & 3.0 & 1.2 & 0.40 & 6.7 & 1.7 & 0.25 & 120 & 10 \\
\hline 15 & rhDNAse & 2.5 & 1.3 & 0.52 & 8.6 & 3.1 & 0.36 & 80 & 2 \\
\hline 16 & No & 4.7 & 1.4 & 0.30 & 10.7 & 2.3 & 0.21 & 200 & 13 \\
\hline 17 & rhDNAse & 2.0 & 1.2 & 0.60 & 9.7 & 3.4 & 0.35 & 120 & 0.3 \\
\hline 18 & No & 44 & 12 & 0.27 & 93 & 18 & 0.19 & 12,000 & 16 \\
\hline 19 & No & 1.6 & 0.8 & 0.50 & 3.7 & 0.9 & 0.24 & 250 & 7 \\
\hline 20 & No & 0.8 & 0.4 & 0.50 & 2.3 & 0.8 & 0.35 & 36 & 3 \\
\hline non-CF & No & 0.5 & 0.3 & 0.60 & 1.8 & 0.8 & 0.44 & 20 & 0.3 \\
\hline
\end{tabular}

\subsection{Ex Vivo Sputum Treatment}

In order to confirm the role of rhDNAse, the sputum previously harvested from a non-conditioned patient was treated with an aerosol of rhDNAse. The results obtained under in vitro conditions (Figure 3) clearly confirm the effect of rhDNAse on the apparent yield stress. Moreover, we wondered whether N-acetyl-cysteine (NAC), which only affects the mucin network [23], could also induce a decrease in the apparent yield stress. As shown in Figure 3, ex vivo NAC treatment of the same sputum leads to a much smaller decrease in the apparent yield stress than rhDNAse treatment. 
A)

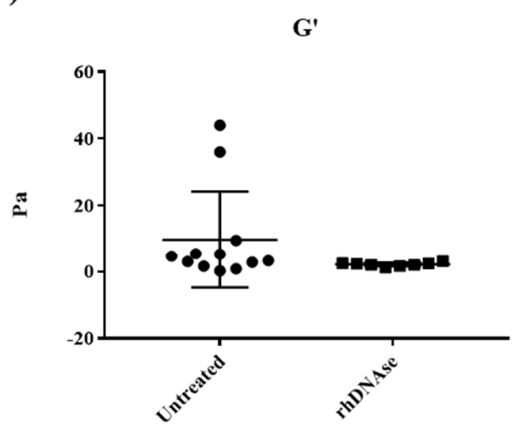

G'

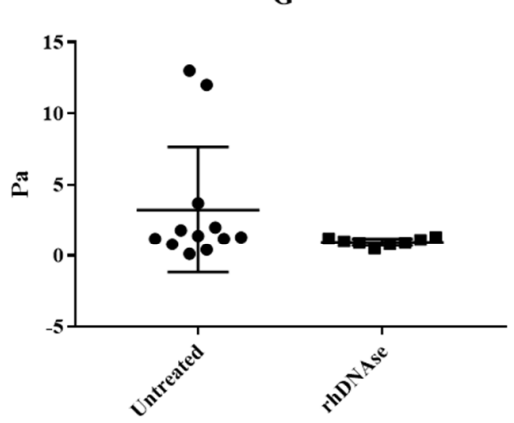

$\tan \delta$

B)
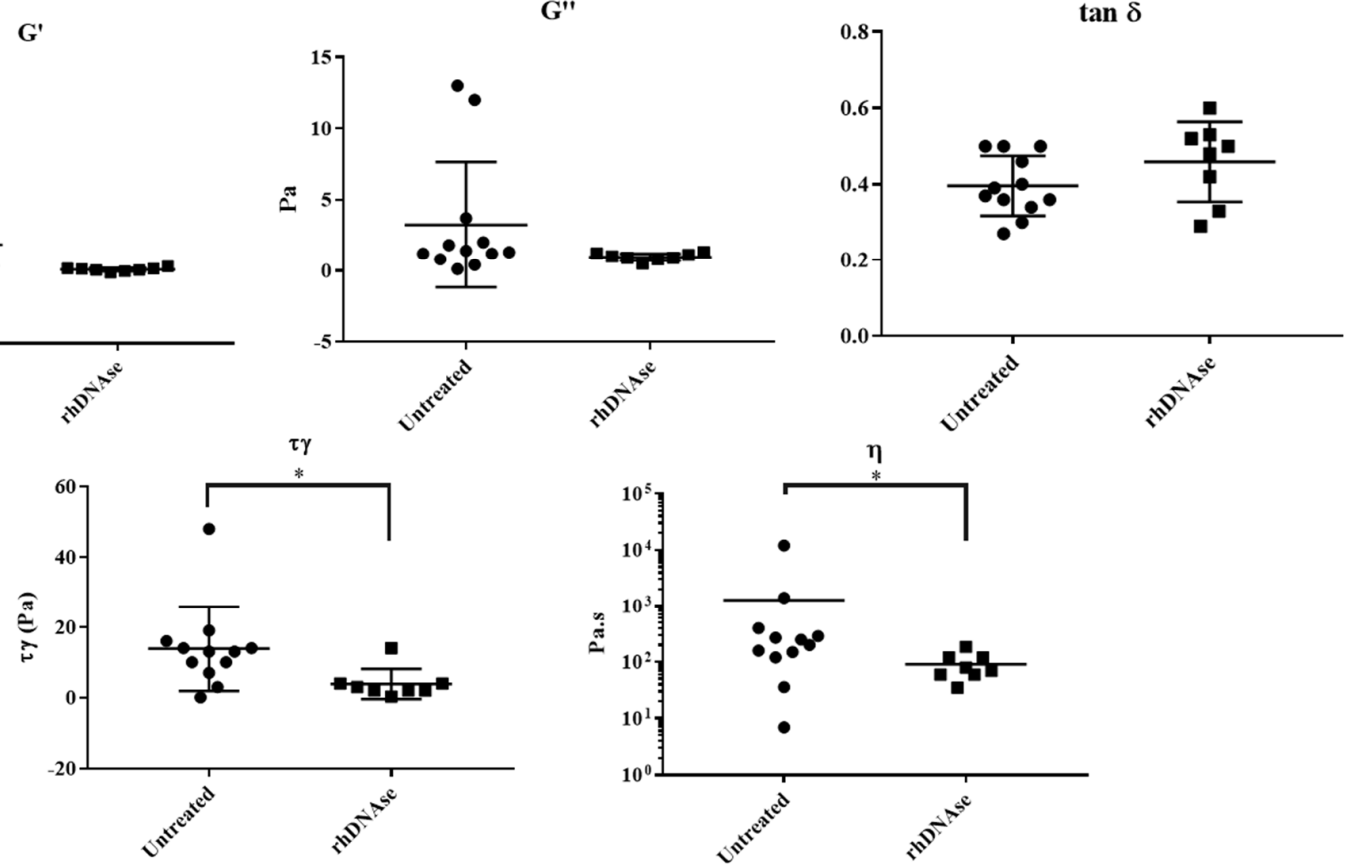

$\eta$

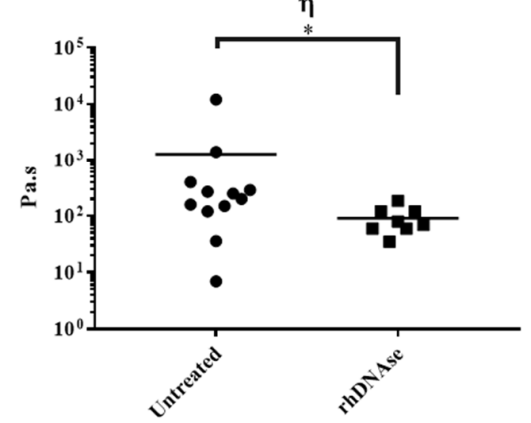

Figure 2. (A) Graphical comparison of rheological data obtained in oscillatory and steady shear flow of mucus from spontaneous or induced CF expectoration collected for this study. Storage modulus $\left(G^{\prime}\right)$ and loss modulus $\left(G^{\prime \prime}\right)$ data were measured at a strain amplitude of $1 \%$ and at an angular frequency of 0.1 rad.s ${ }^{-1}$ and $\tan \delta=G^{\prime \prime} / G^{\prime}$. (B) Graphical comparison of apparent yield stress $\left(\tau_{\gamma}\right)$ and Newtonian viscosity $(\eta)$ of untreated and rhDNAse-treated mucus. Statistical analysis with the non-parametric Mann-Whitney test was performed to compare $\tau_{\gamma}$ and $\eta$ values in patients from the two groups; the symbol "*" denotes a $p$ value $<5 \%$.

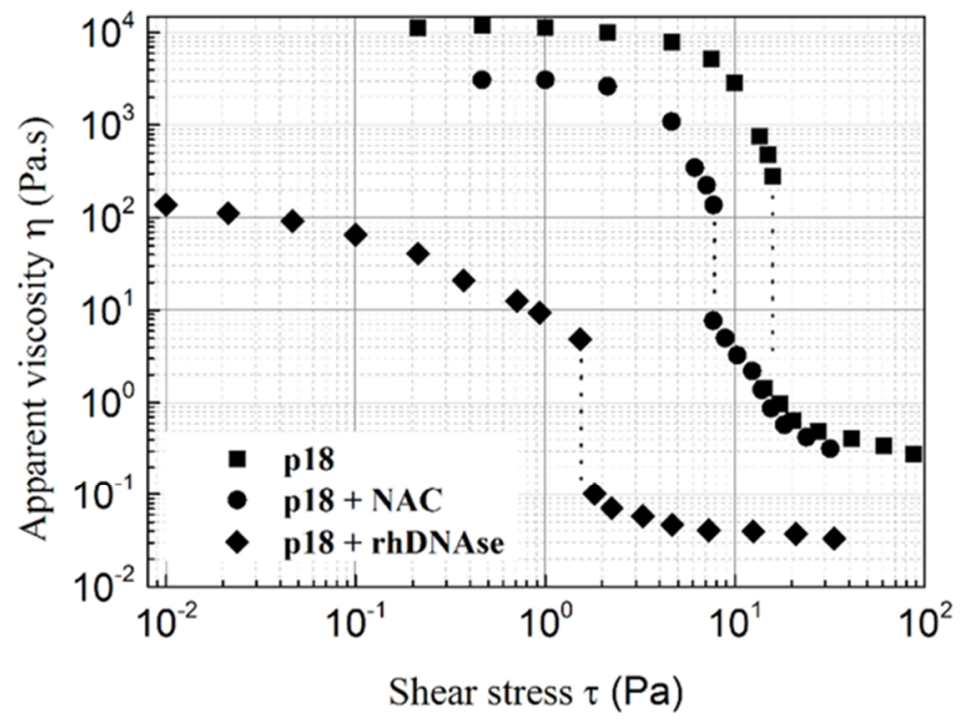

\begin{tabular}{ccc}
\hline & $\boldsymbol{\eta}_{\mathbf{0}}$ (Pa.s) & $\boldsymbol{\tau}_{\mathbf{y}}(\mathbf{P a})$ \\
\hline p18 & 12000 & 16 \\
$\mathbf{p 1 8}+$ NAC & 3100 & 8 \\
\hline 18 + rhDNAse & 150 & 1.5 \\
\hline
\end{tabular}

Figure 3. Flow curves, Newtonian viscosity $\left(\eta_{0}\right)$ and apparent yield stress $\left(\tau_{\gamma}\right)$ of sputum collected from p18 (collected without rhDNAse induction) and treated or not with either rhDNAse or N-acetylcysteine (NAC). The apparent yield stress is defined as the stress at the flow curve near discontinuity. 


\section{Discussion}

The major role played by extracellular DNA in the structure of CF mucus could explain the effect of rhDNAse, which only and directly affects the DNA/actin network, on the apparent yield stress. Indeed, the amount of extracellular DNA in CF mucus is much higher than in non-CF mucus $[24,25]$. The mucus structure is quite complex, consisting of a network involving interactions between mucin and non-mucin proteins, forming the mucus scaffold [26]. Extracellular DNA contributes to the structural and viscoelastic properties of mucus by forming bundles with F-actin, which are connected within a network, consolidating the mucin network [27-30]. In addition, due to chronic infections, the presence of bacterial biofilm, non-homogeneously distributed within the sputum, has to be a priori considered, as it is known to also exhibit viscoelastic properties [31-33]. Treatment with rhDNAse affects the DNA/actin network: it leads to a reduction in both the concentration and size of extracellular DNA, which is responsible for the fracture of the DNA/actin network [34,35]. The small effect of NAC, which only affects the mucin network, on the apparent yield stress indirectly confirms that the higher apparent yield stress is due to the breakdown of the DNA/actin network. This interpretation is also supported by the fact that rhDNAse has virtually no effect on CF biofilm [36] or on the mucin network [37]. Moreover, as non-CF sputum is devoid of biofilm, but still exhibits an apparent yield stress of the same order of magnitude as that of treated sputum, we propose that the low apparent yield stress can be attributed to the destruction of the mucin network. The overall results of the present study therefore strongly suggest that the higher apparent yield stress is a rheological signature of the destruction of the DNA/actin network, whereas the lower apparent yield stress is a rheological signature of the mucin network. In order to give a summary picture, a schematic illustration of the structure of CF sputum, as well as the effect of rhDNAse and NAC, is given in Figure 4.

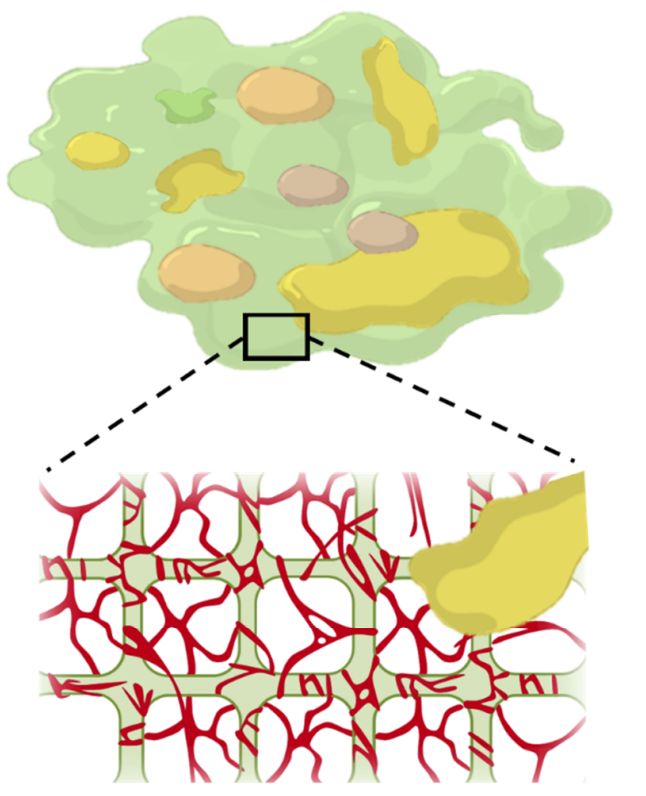

$\tau_{\mathrm{y}} \mathbf{1}$
CF sputum

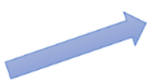

rhDNAse

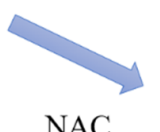

$\mathrm{NAC}$

$$
\tau_{\mathrm{y}} 1>>\tau_{\mathrm{y}} 3>\tau_{\mathrm{y}} 2
$$
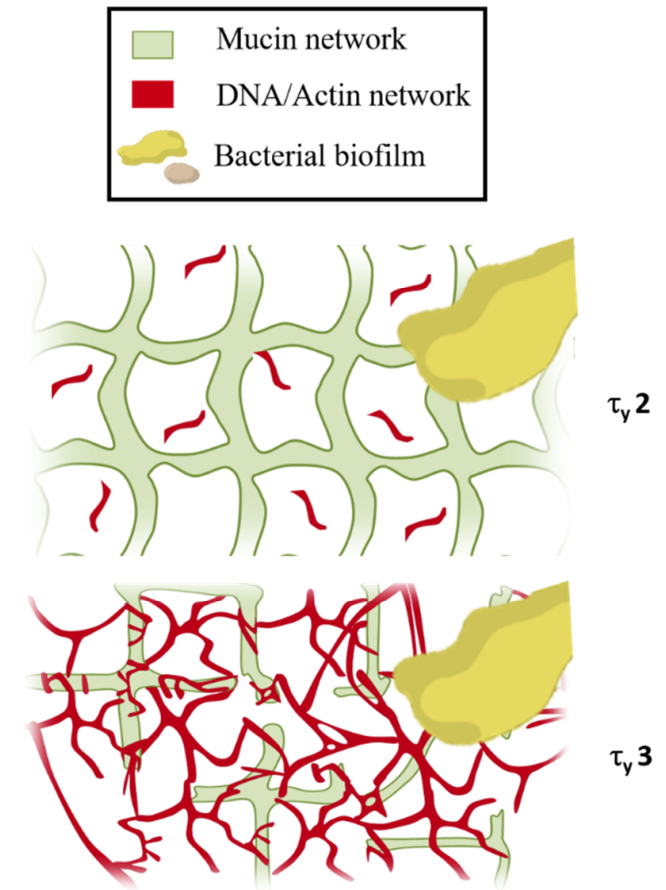

$\tau_{\mathrm{y}} 3$

Figure 4. Schematic representation of CF sputum composed of two distinct networks and bacterial biofilm. Mucin and DNA/actin networks are interconnected. Untreated CF sputum exhibits high yield stress $\left(\tau_{\gamma} 1\right)$. When CF sputum is treated with rhDNAse, the mucin network is preserved but DNA/actin network is broken, leading to the decrease in the apparent yield stress to the same level as that of non-CF sputum $\left(\tau_{\gamma} 2\right)$. On the other hand, when CF sputum is exposed to NAC (N-acetyl-cysteine), some of the disulfide bridges of the mucin network are broken, but the DNA/actin network is largely preserved, resulting in a slightly lower decrease in the yield stress $\left(\tau_{\gamma} 3\right)$. 


\section{Conclusions}

In the present study, linear viscoelastic properties (storage modulus $\mathrm{G}^{\prime}$ and loss modulus $\mathrm{G}^{\prime \prime}$ ), as well as flow properties (Newtonian viscosity, yield stress), of CF sputa were characterized. Interestingly, the apparent yield stress, rather than the linear viscoelastic moduli $G^{\prime}$ and $G^{\prime \prime}$ and even the Newtonian viscosity, turned out to be the most relevant biomarker for the development and the monitoring of mucolytic agents acting on the DNA/actin network. This could also be used as a key parameter to study the efficiency of new pharmacological therapies such as Trikafta ${ }^{\circledR}$ or prior to gene therapy delivery, as well as in the development of in vitro mucus models for the screening of new drugs or the improvement of their formulations [38,39].

Supplementary Materials: The following are available online at https: / / www.mdpi.com/article / 10.3390/ cells10113107/s1, Figure S1: Investigation of possible slip effects, Figure S2: Determination of the linear viscoelastic domain.

Author Contributions: R.G., V.L., T.L.G. and T.M. conceived the project. P.R. and R.G. contributed to sample preparation and carried out the experiments. P.R. and R.G. performed data analyses. T.A. and T.M. verified the analyses. S.R., V.L. and T.H. provided samples and supported the project. R.G., T.A. and T.M. wrote the initial manuscript. All authors provided critical feedback and contributed to the final manuscript. All authors have read and agreed to the published version of the manuscript.

Funding: This work was supported by "Vaincre la mucoviscidose" (Paris, France), "ANR-Agence Nationale de la Recherche" (project n ${ }^{\circ}$ ANR-17-CE18-0015-03 "monopDNA-Nanoparticules VirusInspirées pour transfert de gènes) and "Association de transfusion sanguine et de biogénétique Gaétan Saleün" (Brest, France). R.G. is grateful for a PhD fellowship from the Brest Métropole and Association Gaétan Saleün.

Institutional Review Board Statement: The study was approved by the "Centre de Ressources et de Compétences de la Mucoviscidose, Fondation Ildys, Presqu'île de Perharidy, 29680, Roscoff, France".

Informed Consent Statement: Informed consent was obtained from all subjects involved in the study. Data Availability Statement: Not applicable.

Acknowledgments: The authors are grateful to Julian Ravel for English reviewing, to Kevin Pluchon and Mégane Floch for collecting mucus and to Jérémy Le Joncour for his graphical support.

Conflicts of Interest: The authors declare no conflict of interest.

\section{References}

1. Elborn, J.S. Cystic fibrosis. Lancet 2016, 388, 2519-2531. [CrossRef]

2. O'Sullivan, B.P.; Freedman, S.D. Cystic fibrosis. Lancet 2009, 373, 1891-1904. [CrossRef]

3. Dhooghe, B.; Noel, S.; Huaux, F.; Leal, T. Lung inflammation in cystic fibrosis: Pathogenesis and novel therapies. Clin. Biochem. 2014, 47, 539-546. [CrossRef]

4. Middleton, P.G.; Mall, M.A.; Dřevínek, P.; Lands, L.C.; McKone, E.F.; Polineni, D.; Ramsey, B.W.; Taylor-Cousar, J.L.; Tullis, E.; Vermeulen, F.; et al. Elexacaftor-Tezacaftor-Ivacaftor for Cystic Fibrosis with a Single Phe508del Allele. N. Engl. J. Med. 2019, 381, 1809-1819. [CrossRef] [PubMed]

5. Hoy, S.M. Elexacaftor/Ivacaftor/Tezacaftor: First Approval. Drugs 2019, 79, 2001-2007. [CrossRef]

6. Burgel, P.-R.; Munck, A.; Durieu, I.; Chiron, R.; Mely, L.; Prevotat, A.; Murris-Espin, M.; Porzio, M.; Abely, M.; Reix, P.; et al. Real-Life Safety and Effectiveness of Lumacaftor-Ivacaftor in Patients with Cystic Fibrosis. Am. J. Respir. Crit. Care Med. 2020, 201, 188-197. [CrossRef]

7. Safirstein, J.; Grant, J.J.; Clausen, E.; Savant, D.; Dezube, R.; Hong, G. Biliary disease and cholecystectomy after initiation of elexacaftor/ivacaftor/tezacaftor in adults with cystic fibrosis. J. Cyst. Fibros. 2020, 20, 506-510. [CrossRef] [PubMed]

8. Alton, E.W.; Baker, A.; Baker, E.; Boyd, A.C.; Cheng, S.H.; Coles, R.L.; Collie, D.D.S.; Davidson, H.; Davies, J.C.; Gill, D.R.; et al. The safety profile of a cationic lipid-mediated cystic fibrosis gene transfer agent following repeated monthly aerosol administration to sheep. Biomaterials 2013, 34, 10267-10277. [CrossRef]

9. Duncan, G.; Jung, J.; Hanes, J.; Suk, J.S. The Mucus Barrier to Inhaled Gene Therapy. Mol. Ther. 2016, 24, 2043-2053. [CrossRef] [PubMed]

10. Hwang, S.H.; Litt, M.; Forsman, W.C. Rheological properties of mucus. Rheol. Acta 1969, 8, 438-448. [CrossRef]

11. Puchelle, E.; Zahm, J.; Quemada, D. Rheological properties controlling mucociliary frequency and respiratory mucus transport. Biorheology 1987, 24, 557-563. [CrossRef] [PubMed] 
12. King, M.; Zahm, J.; Pierrot, D.; Vaquez-Girod, S.; Puchelle, E. The role of mucus gel viscosity, spinnability, and adhesive properties in clearance by simulated cough. Biorheology 1989, 26, 737-745. [CrossRef]

13. Shak, S.; Capon, D.J.; Hellmiss, R.; Marsters, S.A.; Baker, C.L. Recombinant human DNase I reduces the viscosity of cystic fibrosis sputum. Proc. Natl. Acad. Sci. USA 1990, 87, 9188-9192. [CrossRef] [PubMed]

14. Serisier, D.J.; Carroll, M.P.; Shute, J.K.; Young, S.A. Macrorheology of cystic fibrosis, chronic obstructive pulmonary disease \& normal sputum. Respir. Res. 2009, 10, 63. [CrossRef] [PubMed]

15. Patarin, J.; Ghiringhelli, E.; Darsy, G.; Obamba, M.; Bochu, P.; Camara, B.; Quétant, S.; Cracowski, J.-L.; Cracowski, C.; Vincent, M.R.D.S. Rheological analysis of sputum from patients with chronic bronchial diseases. Sci. Rep. 2020, 10, 15685. [CrossRef]

16. Ewoldt, R.; Hosoi, A.E.; McKinley, G. New measures for characterizing nonlinear viscoelasticity in large amplitude oscillatory shear. J. Rheol. 2008, 52, 1427-1458. [CrossRef]

17. Ma, J.T.; Tang, C.; Kang, L.; Voynow, J.A.; Rubin, B.K. Cystic Fibrosis Sputum Rheology Correlates With Both Acute and Longitudinal Changes in Lung Function. Chest 2018, 154, 370-377. [CrossRef]

18. Møller, P.C.F.; Mewis, J.; Bonn, D. Yield stress and thixotropy: On the difficulty of measuring yield stresses in practice. Soft Matter 2006, 2, 274-283. [CrossRef] [PubMed]

19. Berret, J.-F.; Séréro, Y. Evidence of Shear-Induced Fluid Fracture in Telechelic Polymer Networks. Phys. Rev. Lett. 2001, 87, 048303. [CrossRef]

20. Aubry, T.; Moan, M. Rheological behavior of a hydrophobically associating water soluble polymer. J. Rheol. 1994, 38, 1681-1692 [CrossRef]

21. Bossard, F.; Aubry, T.; Gotzamanis, G.; Tsitsilianis, C. pH-Tunable rheological properties of a telechelic cationic polyelectrolyte reversible hydrogel. Soft Matter 2006, 2, 510-516. [CrossRef] [PubMed]

22. Shak, S. Aerosolized Recombinant Human DNase I for the Treatment of Cystic Fibrosis. Chest 1995, 107, 65S-70S. [CrossRef]

23. Vukosavljevic, B.; Murgia, X.; Schwarzkopf, K.; Schaefer, U.F.; Lehr, C.-M.; Windbergs, M. Tracing molecular and structural changes upon mucolysis with $\mathrm{N}$-acetyl cysteine in human airway mucus. Int. J. Pharm. 2017, 533, 373-376. [CrossRef] [PubMed]

24. Lethem, M.I.; James, S.L.; Marriott, C.; Burke, J.F. The origin of DNA associated with mucus glycoproteins in cystic fibrosis sputum. Eur. Respir. J. 1990, 3, 19-23. [PubMed]

25. Kirchner, K.K.; Wagener, J.S.; Khan, T.Z.; Copenhaver, S.C.; Accurso, F.J. Increased DNA levels in bronchoalveolar lavage fluid obtained from infants with cystic fibrosis. Am. J. Respir. Crit. Care Med. 1996, 154, 1426-1429. [CrossRef] [PubMed]

26. Meldrum, O.W.; Yakubov, G.E.; Bonilla, M.R.; Deshmukh, O.; McGuckin, M.A.; Gidley, M.J. Mucin gel assembly is controlled by a collective action of non-mucin proteins, disulfide bridges, $\mathrm{Ca}^{2+}$-mediated links, and hydrogen bonding. Sci. Rep. 2018, 8, 5802. [CrossRef]

27. Kater, A.; Henke, M.O.; Rubin, B.K. The Role of DNA and Actin Polymers on the Polymer Structure and Rheology of Cystic Fibrosis Sputum and Depolymerization by Gelsolin or Thymosin Beta. Ann. N. Y. Acad. Sci. 2007, 1112, 140-153. [CrossRef]

28. Vasconcellos, C.A.; Allen, P.G.; Wohl, M.E.; Drazen, J.M.; Janmey, P.A.; Stossel, T.P. Reduction in Viscosity of Cystic Fibrosis Sputum in Vitro by Gelsolin. Science 1994, 263, 969-971. [CrossRef]

29. Mrsny, R.; Daugherty, A.; Short, S.; Widmer, R.; Siegel, M.; Keller, G.-A. Distribution of DNA and Alginate in Purulent Cystic Fibrosis Sputum: Implications to Pulmonary Targeting Strategies. J. Drug Target. 1996, 4, 233-243. [CrossRef]

30. Sheils, C.A.; Käs, J.; Travassos, W.; Allen, P.G.; Janmey, P.A.; Wohl, M.E.; Stossel, T.P. Actin filaments mediate DNA fiber formation in chronic inflammatory airway disease. Am. J. Pathol. 1996, 148, 919-927.

31. Körstgens, V.; Flemming, H.-C.; Wingender, J.; Borchard, W. Uniaxial compression measurement device for investigation of the mechanical stability of biofilms. J. Microbiol. Methods 2001, 46, 9-17. [CrossRef]

32. Peterson, B.; He, Y.; Ren, Y.; Zerdoum, A.; Libera, M.R.; Sharma, P.K.; Van Winkelhoff, A.-J.; Neut, D.; Stoodley, P.; Van Der Mei, H.C.; et al. Viscoelasticity of biofilms and their recalcitrance to mechanical and chemical challenges. FEMS Microbiol. Rev. 2015, 39, 234-245. [CrossRef]

33. Gloag, E.S.; German, G.K.; Stoodley, P.; Wozniak, D.J. Viscoelastic properties of Pseudomonas aeruginosa variant biofilms. Sci. Rep. 2018, 8, 9691. [CrossRef]

34. Brandt, T.; Breitenstein, S.; Von Der Hardt, H.; Tummler, B. DNA concentration and length in sputum of patients with cystic fibrosis during inhalation with recombinant human DNase. Thorax 1995, 50, 880-882. [CrossRef]

35. Ratjen, F.; Paul, K.; van Koningsbruggen, S.; Breitenstein, S.; Rietschel, E.; Nikolaizik, W.; for the BEAT Study Group. DNA concentrations in BAL fluid of cystic fibrosis patients with early lung disease: Influence of treatment with dornase alpha. Pediatr. Pulmonol. 2004, 39, 1-4. [CrossRef] [PubMed]

36. Whitchurch, C.B.; Tolker-Nielsen, T.; Ragas, P.C.; Mattick, J.S. Extracellular DNA Required for Bacterial Biofilm Formation. Science 2002, 295, 1487. [CrossRef]

37. Esther, C.R., Jr.; Muhlebach, M.S.; Ehre, C.; Hill, D.B.; Wolfgang, M.C.; Kesimer, M.; Ramsey, K.A.; Markovetz, M.R.; Garbarine, I.C.; Forest, M.G.; et al. Mucus accumulation in the lungs precedes structural changes and infection in children with cystic fibrosis. Sci. Transl. Med. 2019, 11, eaav3488. [CrossRef] [PubMed] 
38. Ghanem, R.; Laurent, V.; Roquefort, P.; Haute, T.; Ramel, S.; Le Gall, T.; Aubry, T.; Montier, T. Optimizations of In Vitro Mucus and Cell Culture Models to Better Predict In Vivo Gene Transfer in Pathological Lung Respiratory Airways: Cystic Fibrosis as an Example. Pharmaceutics 2020, 13, 47. [CrossRef] [PubMed]

39. Zierden, H.C.; Josyula, A.; Shapiro, R.L.; Hsueh, H.T.; Hanes, J.; Ensign, L.M. Avoiding a Sticky Situation: Bypassing the Mucus Barrier for Improved Local Drug Delivery. Trends Mol. Med. 2021, 27, 436-450. [CrossRef] [PubMed] 